\title{
Understanding the Trembles of Nature: How Do Disaster Experiences Shape Bank Risk Taking?
}

Citation for published version (APA):

Bos, J., \& Li, R. (2017). Understanding the Trembles of Nature: How Do Disaster Experiences Shape Bank Risk Taking? Maastricht University, Graduate School of Business and Economics. GSBE Research Memoranda No. 033 https://doi.org/10.26481/umagsb.2017033

Document status and date:

Published: 14/12/2017

DOI:

10.26481/umagsb.2017033

Document Version:

Publisher's PDF, also known as Version of record

\section{Please check the document version of this publication:}

- A submitted manuscript is the version of the article upon submission and before peer-review. There can be important differences between the submitted version and the official published version of record.

People interested in the research are advised to contact the author for the final version of the publication, or visit the DOI to the publisher's website.

- The final author version and the galley proof are versions of the publication after peer review.

- The final published version features the final layout of the paper including the volume, issue and page numbers.

Link to publication

\footnotetext{
General rights rights.

- You may freely distribute the URL identifying the publication in the public portal. please follow below link for the End User Agreement:

www.umlib.nl/taverne-license

Take down policy

If you believe that this document breaches copyright please contact us at:

repository@maastrichtuniversity.nl

providing details and we will investigate your claim.
}

Copyright and moral rights for the publications made accessible in the public portal are retained by the authors and/or other copyright owners and it is a condition of accessing publications that users recognise and abide by the legal requirements associated with these

- Users may download and print one copy of any publication from the public portal for the purpose of private study or research.

- You may not further distribute the material or use it for any profit-making activity or commercial gain

If the publication is distributed under the terms of Article $25 \mathrm{fa}$ of the Dutch Copyright Act, indicated by the "Taverne" license above, 


\section{Maastricht University}

Jaap Bos, Runliang Li

Understanding the Trembles of Nature: How do Disaster Experiences Shape Bank Risk Taking?

$\mathrm{RM} / 17 / 033$

\section{GSBE}

Maastricht University School of Business and Economics

Graduate School of Business and Economics

P.O Box 616

NL- 6200 MD Maastricht

The Netherlands 


\title{
Understanding the Trembles of Nature: How Do Disaster Experiences Shape Bank Risk Taking?
}

\author{
Jaap Bos Runliang Li*
}

December 8, 2017

\begin{abstract}
This paper examines the impact of natural disaster experiences on banks' business practices. Using earthquake and banking data for California, we find that banks that have had stronger earthquake experiences change their practices, both as a result of the natural disasters' effects on local deposit supply and through changes in banks' risk perceptions. These banks have a smaller exposure to real estate, maintain higher equity levels, and are more likely to lend to high-income borrowers. This paper confirms, therefore, that institutional memory exists in the banking sector and that banks and communities adapt to natural disasters interactively.
\end{abstract}

JEL Codes: D53, D83, G11, G21, Q54

\section{Introduction}

Banks lend funds to companies and households, thereby ideally promoting and sustaining firm productivity and enhancing customers' welfare. The extent to which banks can perform this role can be greatly affected by shocks, in particular natural hazards. It is

*Bos: Maastricht University School of Business and Economics, P.O. Box 616, 6200 MD, Maastricht, The Netherlands, j.bos@maastrichtuniversity.nl. Li: Maastricht University School of Business and Economics, P.O. Box 616, 6200 MD, Maastricht, The Netherlands, r.li@maastrichtuniversity.nl. The usual disclaimer applies. 
commonly known that natural disasters affect banks in two distinct ways. On the one hand, natural disasters temporarily stimulate the demand for loans by destroying firms' productive capital and household property. On the other hand, natural disasters usually trigger defaults of existing loans and therefore may lead banks to become more cautious in issuing loans, resulting in an insufficient credit supply to support economic recovery.

There is ample evidence on how banks adjust their asset structures and lending activities after various types of natural disasters (Berg and Schrader, 2012; Chavaz, 2014; Collier et al., 2011; Cortés and Strahan, 2017; Klomp, 2014). However, most studies focus on the immediate response of banks to catastrophes and overlook the long-term impact of disaster experiences on banks' balance sheet structures and lending patterns.

In this paper, we argue that examining the long-run relationship between banks and natural disasters affords us with important additional insights on the effects of large shocks to the financial sector. A first insight relates to the long-run changes in the supply of banks' funds as a result of disaster experiences. For example, we know already that banks are sensitive to their exposure to real estate because real estate loans are prone to defaults after a shock (Hott, 2011). But it is more interesting to know how banks adjust their real estate lending in the long run. Of course, banks that repeatedly experience disaster-related defaults tend to purposefully contract their real estate loans. But such a reduction in loans may also reflect changes in external market forces. Specifically, intense disaster experiences can lead to reallocation of economic activities from one county to another, resulting in a long-run drop in either banks deposits or the demand for real estate loans. A short-run analysis cannot capture such a gradual demographic and economic evolution, which is why we need a long-term investigation.

A second insight relates to the resilience of banks to future shocks. After all, even if we know that banks with a higher equity buffer can better satisfy the disaster-driven increase in credit demand than banks with a lower equity level, we still need to establish whether such adeptness is the result of them having gradually learned from their hazard experiences, or whether each new shock triggers a reaction that is independent of previous disaster experiences. If banks have indeed become more prudent and then decide to keep a higher capital level after learning from their past disaster experiences, they will be more resilient to future disasters. We therefore study how long-run disaster experiences have 
shaped banks equity buffers.

A third and final insight relates to quality adjustments as a result of disaster experiences. In addition to reforming their balance sheet structure to enhance their resilience to future shocks, banks that have stronger disaster experiences may adjust their loan quality. Though theories have predicted that higher capital enhances screening and monitoring and thus promotes the access to credit of poor borrowers (Holmstrom and Tirole, 1997; Mehran and Thakor, 2011), banks may still switch to high-income borrowers if disasters have increased the perceived riskiness of their loans to a great extent. Furthermore, by tightening the budget constraint, repeated disasters may worsen the discrimination issue in ethnic minorities' loan applications if banks have subjective bias against minority people. Motivated by these concerns, we study how long-run natural disaster experiences have affected banks' lending preferences.

These insights are closely related. Put it simply, to protect themselves from losses, banks repeatedly experiencing disaster-related defaults may boost their capital level, reduce their exposure to risky loans, and target borrowers with a better credit quality. Each of these attempts at reducing disaster risk exposure has its own distinct features. Except for the capitalization that largely captures the bank's own risk expectation, both the real estate loan and lending patterns are heavily determined by market forces. Specifically, by triggering the flow of migrants (Elliott, 2014), disasters change the residential composition of a region (e.g. income level, labor productivity, and race), alter the supply of deposits or the demand for loans, and resultantly affect the level of risky loans and lending patterns of banks. In this respect, my risk-taking measures weave together a general equilibrium story, which, to my knowledge, has not been fully documented either by theoretical or empirical studies.

In this paper, we therefore answer three, related research questions. First, we examine whether banks having stronger disaster experiences maintain a lower level of real estate loans and a higher level of capital. Second, we study whether higher disaster exposure leads banks to prefer high-income borrowers and become more biased against ethnic minorities when extending loans. Third, in order to explore what makes long-run disaster experiences particularly salient for the decision making of banks and to address the long-run changes banks' customer bases, we analyze the supply and demand sides 
of bank funds, that is, whether the local population and deposits in bank branches have changed over the past years because of natural disasters.

To answer these related questions, we focus on banks (1994 to 2013) and earthquakes (1769 to 2013) in California. The reasons for choosing California are threefold. First, earthquakes are the dominant natural hazard in California, occurring with a relatively high frequency compared to other types of disasters. ${ }^{1}$ Second, since earthquakes happen frequently and have received much attention from research institutes and the state government, historical earthquake records are abundant and easy to retrieve. Third, the California state government provides exemplary access to various economic and demographic data, e.g. unemployment rate, population, and household income. Such comprehensiveness of the data allows me to robustly identify the effect of the earthquake experience.

My results confirm that long-run experiences do affect banks' risk attitudes and resilience to future shocks by altering the balance sheet structure and loan quality. Specifically, we find that banks that have had more intense earthquake experiences maintain a lower level of real estate loans, boost their equity buffer, and prefer high-income borrowers compared with banks having less intense experiences. For example, an increase in the earthquake experience from its $10^{\text {th }}$ percentile to its $90^{\text {th }}$ percentile is associated with a decrease in the proportion of real estate loan to total assets of 3.1 percent and a decrease in interest income of 4.9 percent. Further, using deposit data at the branch level and demographic data at the county level, we find such changes are related to the evolution of local deposit supply. Particularly, more intense disaster experiences lead to decreases in both the deposit supply and the median household income. Last but not least, we find that banks whose earthquake experiences are in the bottom decile tend to increase their real estate loans and reduce their equity level, indicating that banks continuously surviving from smaller disasters may become more risk-loving. In every regression, the coefficient on the experience variable is significant even after controlling for geographic diversification (as will be explained in Section 2).

\footnotetext{
${ }^{1}$ Another major type of disaster in California is wildfire. But unlike earthquakes that can hit both the residential and non-residential areas, wildfires mainly occur in non-residential regions and thus have little effect on banks.
} 
My study connects to three strands of literature. First, the literature on macroeconomic experiences and individuals' risk taking shows that investors who have experienced high stock market returns are more willing to take risks (Malmendier and Nagel, 2011), and that banks that have undergone difficult economic periods tend to maintain a higher capital level and are more prudential in issuing loans (Bouwman and Malmendier, 2015). We contribute to this literature by showing that, besides economic factors, natural hazards can also affect banks' risk attitudes and alter their asset structure in the long run.

Second, my paper complements the currently popular literature on the relationship between natural disasters and bank lending (Berg and Schrader, 2012; Chavaz, 2014; Collier et al., 2011; Cortés and Strahan, 2017). Particularly, by verifying that banks adjust their balance sheet structure according to their long-term disaster experiences, we show that the response of a bank to a new disaster depends on its own disaster history. Further, my results confirm that early earthquakes do not easily fade away from the memory of banks and thus significantly influence banks' current financial decisions.

Third, by investigating the channels making disaster experiences crucial for banks, my paper connects to the financing growth literature (King and Levine, 1993; Levine, 1997; Pagano, 1993). Importantly, we show that communities also learn from earthquake experiences, leading to changes in their population and income structures throughout the history. Such evolution is responsible for changes in the business practices of banks. To sum up, to the best of my knowledge, my study is the first to link the balance sheet structure and loan quality of banks to their long-term natural disaster experiences.

The paper proceeds as follows. Section 2 introduces the data, visualizes earthquakes, and summarizes key statistics. Section 3 explains the empirical method and identification strategy. Section 4 presents and interprets my empirical results, explores changes in market forces associated with disaster experiences, and discusses robustness checks. Section 5 concludes. 


\section{Data, Variables, and Descriptive Statistics}

We use data from a variety of sources to construct my variables of interest. In this section, we explain how to obtain my data and compile variables. The key dependent variables are measures of risk taking while the chief explanatory variable is the earthquake experience.

\subsection{Measures of Risk Taking}

My measures of risk taking can be classified into two categories. The first set of measures is based on the balance sheet structure of banks. Following the common practice, we use capital ratios and the share of risky loans to measure risk taking. The second set of measures is based on banks' lending inclination. Specifically, we examine whether banks tend to be biased toward different types of borrowers in terms of their income and race. ${ }^{2}$

\subsubsection{Measures Based on Balance Sheet Structure}

We construct the capital ratio and the real estate loan ratio with balance sheet information from the quarterly Consolidated Reports of Condition and Income (Call Reports) for all commercial banks of California over the period 1994Q1 to 2013Q4. ${ }^{3}$ The Call Reports data are at the bank level. However, since a bank's disaster experience is an aggregate of its branch-level experiences, we later match branches to their headquarters using bank identifiers.

The level of risky loans is a crucial measure of bank risk taking. Among all types of loans, the real estate loan accounts for the biggest part of the total loans (about 50 percent; see Table 1 for descriptive statistics) and is an important source of income for

\footnotetext{
${ }^{2}$ In this paper, for simplicity we often count among my dependent variables as risk-taking measures. However, except for the capital ratio that is a pure risk-taking measure, all other variables reflect to some extent external market conditions. For instance, real estate loans are partly determined by the supply and demand of funds by consumers and industries and are not fully decided by banks on their own. In fact, exploring the "market forces" channel constitutes an important part of this study and distinguishes my paper from those on individuals' lifetime experiences.

${ }^{3}$ This does not mean, however, that we only have 20 years of records of earthquakes. In fact, since the experience variable is constructed based on bank branches, some of which were established circa 1850, we use the earthquake data from the early 19 th century to the present.
} 
commercial banks. Meanwhile, real estate loans have been recognized as the main culprit of bank failures during the global financial crisis (Cole and White, 2012). Earthquakes can impose tremendous damage to buildings relative to other kinds of natural disasters. We therefore use the real estate ratio, defined as Real estate loan/total assets, as a risk-taking measure.

The capital ratio is a commonly used variable in the literature to characterize the willingness of a bank to take risks (Berger and Bouwman, 2013; Lambert et al., 2015; Thakor, 2014). It measures a bank's amount of equity relative to its total assets. Banks with higher capital have a greater capability of surviving adverse financial conditions (Berger and Bouwman, 2013), while banks with lower capital are more prone to defaults that can be pronounced during natural disaster periods (Collier, 2014). We therefore use the capital ratio as a risk-taking measure. Specifically, in line with Berger and Bouwman (2013), we define the capital ratio as the ratio of total equity to GTA, where GTA is total assets plus the allowance for loan and lease losses and the allocated transfer risk reserve. ${ }^{4}$

\subsubsection{Measures Based on Lending Preferences}

In this study, we go a step further by measuring risk taking from banks' lending preferences. A conservative bank expecting a higher default probability of its loans may carefully evaluate borrowers and choose to lend to those who are able to repay loans in time. In the light of this statement, we construct a borrower income measure and a borrower race measure from the Home Mortgage Disclosure Act (HMDA) data for all California commercial banks over the period 2010 to 2013. The HMDA database contains public loan data for various types of lending institutions, including banks, saving associations, credit unions, and other mortgage lending institutions. A lending institution, say, a branch of a bank, needs to report all loan transactions for a whole calendar year. Each transaction record contains up to 45 variables, including the institution's ID, loan amount, borrower's income, and the borrower's race.

These two measures are at the year-bank level. The borrower income measure is

\footnotetext{
${ }^{4}$ The equity ratio is frequently referred to as "equity ratio", "equity capital ratio", or "capitalization". It is also commonly represented by the Tier 1 risk-based capital ratio defined by Basel III report in many studies (Lambert et al., 2015; Dell'Ariccia et al., 2016).
} 
constructed as follows. For each year, we calculate a bank's mean borrower income by taking the average of all branch-level borrower income. As income is positively related to credit quality, we posit that a bank may prefer to lend to high-income borrowers if stronger earthquake experiences have led the bank to become more risk-averse.

The borrower race measure is defined as the proportion of a bank's nonwhite borrowers each year. Specifically, for every bank, we calculate the ratio of the number of nonwhite borrowers (denoted by 1 to 4 in the "Applicant Race 1" entry) to the number of all borrowers. Since one of the purposes of the HMDA data is to identify possible discriminatory lending patterns, we complement this purpose by exploring whether lending discrimination can be driven by natural disasters that impose fund constraints on banks.

\subsection{Explanatory Variables}

\subsubsection{The Earthquake Experience}

The key explanatory variable in my study is the earthquake experience. Intuitively, it has a straightforward meaning as the measure of how strongly a bank has been affected by earthquakes, which are largely exogenous, during its operating history. One concern is the endogeneity problem that can arise if banks deliberately choose to open in less riskier regions. We tackle this important issue in detail in Section 3.

To construct the earthquake experience variable, we use bank branch data and earthquake data. The branch data are from the Summary of Deposits (SOD) of the FDIC. The SOD is a publicly available annual survey that reports branch-level deposits for all FDIC-insured institutions. Aside from the deposit data, the SOD also records the geographic coordinates, county of location, and the date of establishment for each branch. The headquarter bank of each branch is identified by the FDIC Certificate Number. The data reveal that the history of Californian banks can be dated back to the middle of the nineteenth century. For example, the Bank of Stockton, one of the oldest banks in California, is established on August 12, 1867. To account for earthquake experiences of old banks, we therefore need a long list of historical earthquakes.

Fortunately, the earthquake data of California are available and complete. We compile the earthquake data from two major sources. The first source is the geological survey 
by Stover and Coffman (1993) in PDF format that covers the earthquakes of California from 1769 to 1989. The second source is the Search Earthquake Catalog of the United States Geological Survey (USGS). It is a digital database that contains more comprehensive earthquake records since 1932. Before 1932, however, the USGS records are sparse. To form my earthquake dataset, we therefore manually take the records of Stover and Coffman (1993) from 1769 to 1931 and combine them with the USGS records from 1932 to 2013. The four variables we use to characterize each earthquake are the time of occurrence, latitude, longitude, and the magnitude. As figures convey more powerful information, we plot earthquakes of California from 2006-2010 in Figure 1. The figure confirms that earthquakes are indeed a prevalent natural disaster in California: Events occur nearly all over the state, including the economically developed costal regions. However, there are also a few counties in the middle part of California (the Great Valley) that apparently have few earthquakes. We define this region as the "NonHaz" Region and, in my empirical analysis, we use bank branches in this region to account for possible effects of geographic diversification on the balance sheet structures and lending practices of banks. ${ }^{5}$

We first use the method developed by Malmendier and Nagel (2011) and construct the earthquake experience for each branch $b$ at date $t$ as a weighted average of its past earthquake magnitudes. As shown in equation (1), the weighting scheme is determined by the age of the branch at time $t\left(a g e_{i t}\right)$, the date of the earthquake $\left(\right.$ date $\left._{t-k}\right)$, the date of establishment $\left(\right.$ estdate $\left._{b}\right)$, how long ago the earthquake took place $(k)$, and a shaping parameter $\lambda{ }^{6}$ A decreasing weighting function $(\lambda>0)$ reflects that early earthquake experiences fade away from the memory of the branch. An increasing weighting function $(\lambda<0)$, on the contrary, means that early earthquake experiences can have greater influence on a bank's current decision-making than recent ones. $M_{t-k}$ denotes the earthquake magnitude. We let $M_{t-k}=0$ when the magnitude of the earthquake on date $t_{t-k}$ is less

\footnotetext{
${ }^{5}$ One plausible explanation that the Great Valley region (especially its northern part) has fewer earthquakes than the costal area is that it is relatively far away from the San Andreas Fault, a continental transform fault that extends roughly 1,200 kilometers through California along the east coast.

${ }^{6}$ The term date $_{t-k}-e_{\text {estdate }}$ represents how recent the earthquake is. A smaller value indicates an early earthquake that happened shortly after the date of establishment; a larger value means that the earthquake happened recently.
} 
than 4, or when there was no earthquake; as a result, the branch's earthquake experience on that day is zero. ${ }^{7}$ We also exclude earthquakes happening just one quarter before the current date $t$ (i.e., we let $k$ start at 90 ) to prevent any short-term effects of earthquakes on asset structures and to ensure that banks really behave according to their long-term earthquake experiences:

$$
E_{b t}=\sum_{k=90}^{a g e_{b t}-1} w_{b k}(\lambda) M_{t-k}
$$

where

$$
w_{b k}(\lambda)=\frac{\left(\text { date }_{t-k}-\text { estdate }_{b}\right)^{\lambda}}{\sum_{k=90}^{a g e_{b t}-1}\left(a g e_{b t}-k\right)^{\lambda}} .
$$

Whereas Malmendier and Nagel (2011) focus on an individual investor, the banks in this study have multiple branches operating in different regions, and the earthquake experiences of branches thus differ from each other. In view of this feature, a bank's earthquake experience should eventually be an aggregate of the experiences of its branches. We construct the bank-level earthquake experience by using a set of deposit weights. In particular, as shown in equation (2), each branch $b$ at time $t$ takes a weight equal to the proportion of its deposit in the total deposits of all branches. ${ }^{8}$ The underlying assumption is that if a branch has a higher level of deposit, its headquarter bank consequently attach greater importance to its experiences when making financial decisions. The deposit weight $\omega_{b t}$ changes yearly because the deposit data are reported yearly. Finally, a bank's earthquake experience is the weighted average of branch experiences:

\footnotetext{
${ }^{7}$ Choosing the threshold of 4 implies that banks simply ignore weaker earthquakes. The threshold is based on the effects of earthquakes described on the USGS website (https://earthquake.usgs.gov/ learn/topics/mag_vs_int.php). According to the description, earthquakes with magnitudes between 3.0 and 3.9 are felt quite noticeably by persons indoors, especially on upper floors of buildings. But many people do not recognize it as an earthquake. In addition, earthquakes with magnitudes between 4.0 and 4.9 are felt indoors by many, outdoors by few during the day. At night, some awakened. Dishes, windows, doors disturbed; walls make cracking sound. Sensation like heavy truck struck building. Standing motorcars rocked noticeably. In my robustness checks, to further alleviate the concern about the ad hoc threshold, we vary the threshold magnitude. The major inferences nevertheless hold.

${ }^{8}$ Strictly speaking, the branch notation $b$ should have a subscript $i$ to denote that the branch belongs to bank $i$. We slightly abuse the notation to simplify my explanation, as long as the readers can understand.
} 


$$
E_{i t}=\sum_{b=1}^{B_{i t}} \omega_{b t} E_{b t},
$$

where

$$
\omega_{b t}=\frac{\text { deposit }_{b t}}{\sum_{b=1}^{B_{i t}} \text { deposit }_{b t}} .
$$

Aggregating experiences from the branch level to the bank level changes my interpretation of the shape parameter $\lambda$ slightly. At the branch level, $\lambda$ indicates how does each branch memorize its past earthquakes. For example, a positive $\lambda$ means that early earthquake experiences fade away in the memory of the branch, and the higher the value is, the faster the experiences grow faint. At the bank level, however, $\lambda$ is the average shape parameter of all the branches and to a certain degree can be interpreted as the memorizing pattern of the headquarter bank.

Besides the aggregation process, another feature in my variable construction is that the earthquake weight $w_{b k}$ changes daily. Thanks to the data precision, we obtain the exact dates of earthquake and dates of branch establishment, while the filing times of the Call Reports and HMDA records can be set to the last day of each quarter or year. Specifying $w_{b k}$ on a daily basis improves the precision of the experience variable and generates more variation within a quarter. The small cost is an increased calculation time. For example, we need to calculate nearly 3,650 weights for a branch established 10 years ago.

\subsubsection{Bank Variables}

We use Call Reports and the SOD data to construct the following bank-specific variables. Total assets measures bank size. ROA (net interest income/total assets of last quarter) indicates, given the capital base, how profitable a bank can be. Imputed Interest rate measures the cost of borrowing (for total loans, it equals total interest income/total loans and leases; analogously, for real estate loans, it equals interest income on loans secured by real estate/loans secured by real estate). NonHaz branch\% measures the proportion of branches of a bank in counties that are less prone to earthquakes. Specifically, we manually outline counties of the "NonHaz" Region and divide the number of branches 
of a bank in this region by its total number of branches. Bank age is defined as the difference between the date of observation and the date of establishment of a bank.

\subsubsection{Regional Variables}

My regressions include county-level macroeconomic and demographic variables. These variables serve two major purposes. In the first part of my Results section, they are treated as controls to account for the possibility that local conditions affect bank risk taking. In the second part, we use them as dependent variables to explore how a county's current income level and residential composition is shaped by its historical disaster experiences. We collect the median household income and poverty rate from the Census $\mathrm{Bu}-$ reau, the unemployment rate from the website of Employment Development Department of California, and the population and migration data from the website of Department of Finance of California.

\subsection{Summary Statistics}

Table 1 reports summary statistics for my main variables. Panel A reports the statistics for the full sample. However, to avoid the possibility that big banks can distort the picture, Panel B restricts the sample to banks that have less than or equal to 3 branches. Here, three is the median of the number of branches.

Comparing Panels A and B, we see that smaller banks tend to be younger than the average bank, with a mean age of 12 years rather than 21 years. The comparison also reveals that smaller banks are safer than the average bank as they maintain a higher capital buffer, attract more deposits per branch, and lend to customers with a higher income. The patterns are similar for the real estate loan ratio, ROA and interest rates. ${ }^{9}$ In my analyses, we control for total assets and the number of branches of every bank so the effect of earthquake experiences is not confounded by bank size.

The real estate loan comprises the biggest part of banks' balance sheets, averaging $44 \%$ of total assets, with a large standard deviation of 0.179 . This suggests that the real

\footnotetext{
${ }^{9}$ The above conclusions are based on formal t-tests between banks with more than 3 branches and banks with less than or equal to 3 branches.
} 
estate loan is a qualified measure of the riskiness of the overall portfolio of banks. Furthermore, the average interest rate on real estate loans is $4.4 \%$ and has a small variation across banks and over time. On the contrary, the average interest rate on all loans is $17 \%$, with a standard deviation of 6.514 , indicating that banks possess a diversified loan portfolio and there were substantial changes in the benchmark interest rate over the past years.

In the next section, we introduce how we estimate the effects of earthquake experiences and discuss possible identification issues.

\section{Estimation Method and Identification Strategy}

To analyze the relationship between earthquake experiences and the risk taking of banks measured from the perspective of balance sheet structure (real estate ratio and capital ratio) and lending practice (borrower income and ethnicity), we primarily rely on the following generic regression model:

$$
y_{i t}=\alpha+\beta E_{i t}(\lambda)+\gamma^{\prime} x_{i t}+\epsilon_{i t},
$$

where $y_{i t}$ is one of my four risk-taking measures of bank $i$ at time $t, E_{i t}$ is the earthquake experience of the bank, $\lambda$ is the shape parameter that determines the slope of the weighting scheme, and $x_{i t}$ is a vector of control variables that includes bank characteristics (total assets, ROA, imputed interest rates, bank age, number of branches, and proportion of branches in less hazardous counties) and regional demographics (poverty rate, population, and unemployment rate).

For each branch, the shape parameter $\lambda$ determines the slope of the weighting function. A positive $\lambda$ leads to a downward-sloping curve, meaning that the branch gradually forgets early earthquakes and attach bigger weights to recent earthquakes. A negative $\lambda$ indicates an upward-sloping curve, meaning that early earthquakes have left vivid impression to the branch. If $\lambda$ is zero, then the branch weighs all earthquakes equally.

As shown in equation (1) and (2), $E_{i t}(\lambda)$ is constructed as a nonlinear function of the unknown parameter $\lambda$. Thus to estimate $\beta$ and $\lambda$ simultaneously, nonlinear estimation methods are needed. However, as the number of bank branches in my sample is huge and 
the unit of my earthquake weight $\left(w_{b k}\right)$ is daily, nonlinear methods prove to be exceedingly time-consuming. To improve efficiency, we therefore first estimate the equation on a tightly spaced grid of values for $\lambda(\mathrm{step}=0.02)$ and then use the $\lambda$ and the estimates that lead to the lowest residual sum of squares as my final estimated coefficients. ${ }^{10}$ In this way, we effectively transform a nonlinear regression to several linear regressions by fixing the value of $\lambda$ in every regression. ${ }^{11}$

Despite the exogenous nature of earthquakes, my study still faces a few identification issues. ${ }^{12}$ The first one is that earthquakes are not uniformly distributed within California. As shown in Figure 1, even though earthquakes are prevalent, a few counties in the middle region (especially the northern part of the Great Valley) have significantly less earthquakes than other counties. If banks deliberately choose to open more branches in this "NonHaz" Region (as defined in the Data section), then we cannot judge whether the current balance sheet structure and lending pattern are shaped by this geographical diversification strategy or by the earthquake experiences of banks. By plotting the distribution of bank branches in Figure 2, we can already see that a considerable number of branches are located in the "NonHaz" Region, so banks may have already considered the earthquake hazards when locating their branches. To account for this confounding factor, we calculate for each bank the portion of branches in less hazardous counties and include this variable into my regression.

Another identification issue is related to outliers of earthquake experiences. In my sample, a few big banks have accumulated high values of experiences because they are old and have a large number of branches. We account for this issue by excluding the top $1 \%$ largest banks and by dropping extreme values of earthquake experiences $\left(E_{i t} \geq 100\right)$. We further control for bank ages and the number of branches of banks in my regressions.

\footnotetext{
${ }^{10}$ To put it more in detail, we first try values of $\lambda$ 's with a step of 0.5 . After finding the best value, i.e. the value that yields the lowest residual sum of squares, we try values \pm 0.5 around this best value with a step of 0.02 to pin down my final estimates of $\lambda$ and other coefficients.

${ }^{11}$ This estimation method sacrifices the precision of $\lambda$, but reduces the running time of each of my regression programs from more than seven days to less than seven hours.

${ }^{12}$ It is worth mentioning that a remarkable advantage of studying the effects of earthquakes is the absence of reverse causality. In my case, the risk taking of banks can hardly be thought to cause earthquakes.
} 
To control for the unobserved effect of the headquarter bank, we include dummies of counties where the headquarters are located. Finally, we use year dummies to absorb any unobservable aggregate macroeconomic factors that may affect bank risk taking.

\section{Results}

In this section, we present my main results on the effects of earthquake experiences on bank risk taking. We find that banks with intense earthquake experiences adapt their balance sheet structure to make themselves more resilient to defaults. Meanwhile, these banks are significantly more prudent in their lending practices. We next explore the channel linking earthquake experiences to bank risk taking and show that both the market forces as well as the variations in banks' own risk perceptions drive the risk-taking patterns. We further present a battery of robustness tests showing that the main results remain intact when increasing or decreasing the sample size.

\subsection{Balance Sheet Structure}

\subsubsection{Real Estate Ratio}

We start by linking the experienced earthquakes to the real estate ratio defined as the ratio of loans secured by real estate to total assets. We choose the real estate ratio as an important measure of bank risk taking because real estate loans account for the largest part of total loans and are crucial for the financial stability of banks. Buildings are the most important collateral for loans. As earthquakes can cause tremendous damage to buildings, the real estate ratio measure is therefore especially relevant to my study.

The effect of earthquake experiences on the real estate ratio, however, is not obvious at first glance. As explained before, on the one hand, by causing damages to buildings, earthquakes not only trigger defaults of bank loans but also decrease the value of collateral. Banks that repeatedly suffer from defaults can learn from such experiences and subsequently reduce the issuance of real estate loans. On the other hand, earthquakes create investment opportunities in the future, and therefore possibly increase the demand for bank loans. Moreover, real estate loans may be affected by market conditions. For 
instance, residents with strong earthquake experiences may leave high-risk counties, causing decreases in both supply and demand of funds. Such market forces are explored in the next subsection. Here it suffices to know the overall effect of earthquake experiences on the real estate ratio.

The estimate of -0.219 for the coefficient $\beta$ in column (iii) of Table 2 indicates a significantly negative relationship between earthquake experiences and the real estate ratio. To be more specific, the results imply that an increase in the earthquake experience from its $10^{\text {th }}$ percentile to its $90^{\text {th }}$ percentile is associated with a decrease in real estate ratio of 3.1 percent and a decrease in interest income of 4.9 percent. ${ }^{13}$ This differential effect is economically moderate given the large proportion of real estate loans in total assets (44 percent). However, since the results also reflect the opposite "rebuilding" effect, the actual "experience" effect can be big. In addition, as shown in Figure 1, earthquakes are quite evenly distributed across California, so the distribution of experiences is relatively concentrated. For the whole world, natural disasters are not evenly distributed; therefore the "experience" effect can play a significant role. Furthermore, if the disaster experience increases from its minimum to its maximum, the decrease in the real estate ratio is about 46 percent. This huge difference convincingly underlines the non-negligible effects of disaster experiences.

The value of 0.18 for the shape parameter $\lambda$ corresponds to a weighting curve that is almost flat. It means that although banks attach heavier weights to recent earthquakes, old experiences do not easily fade away from their memory. Compared with the values estimated by Malmendier and Nagel (2011, 2015) for individuals' experiences on stock returns and inflation, the value in my study is quite low. This indicates that institutions do not quickly forget past experiences and may respond less promptly to recent experiences than individuals do.

We have included various bank-specific variables in the regression model. Among them, the NonHaz branch\% is of identification importance because it measures how the

\footnotetext{
${ }^{13}$ We evaluate this differential effect (i.e. the difference between the fitted real estate ratios at the $10^{\text {th }}$ and $90^{\text {th }}$ percentiles of the earthquake experience) at the sample means of the data. The results are the same if we evaluate the differential effects at every observation and obtain the sample average of the individual differential effects.
} 
geographic diversification strategy affects the balance sheet structure. My results point out that banks having more branches in disaster-prone counties maintain less real estate loans. This is not surprising given that - as will be explained latter - the demands for real estate loans in these counties are low.

\subsubsection{Capital Ratio}

Unlike the real estate ratio that is partially affected by the supply and demand forces of the market, the capital ratio is mainly determined by the bank on its own and is therefore a more direct risk-taking measure commonly used in the literature (Thakor, 2014; Bouwman and Malmendier, 2015). In a study on a microfinance institution in Peru, Collier (2014) found that the lender increased its capital ratio during the 1998 El Niño to endure disaster-related default risk. In line with this reasoning, in order to protect them from default risks, banks that frequently suffer from disasters may continuously keep a higher capital ratio than banks that have experienced less disasters. To test this hypothesis, Table 3 presents regression results of the effect of earthquake experiences on the capital ratios of California banks.

The capital ratio is significantly negatively related to the earthquake experience, which means banks with stronger earthquake experiences eventually become more cautious than banks with fewer experiences. Specifically, going from the $10^{\text {th }}$ to the $90^{\text {th }}$ percentile of experiences in column (i) implies, on average, an increase in the capital ratio of 0.2 percent, or equivalently, 265 thousand dollars. The economic magnitude of this differential effect, however, is small compared to the standard deviation for the capital ratio of 11.2 percent. ${ }^{14}$ The results do not change after adding new explanatory variables.

Besides using additional capital to absorb losses induced by defaults, banks can manage their default risks ex ante. Theories have predicted that banks with higher capital are able to engage in more costly screening and monitoring activities (Holmstrom

\footnotetext{
${ }^{14}$ The current analysis does not consider the heterogeneity in experiences. However, in subsection 4.5, we find banks at the bottom decile of the earthquake experience reduce their capital ratio significantly, with a differential effect of -1.1 percent. Meanwhile, the standard deviation of the capital ratio is 2.8 percent. This finding implies that having very low earthquake exposure can significantly increase a bank's risk taking.
} 
and Tirole, 1997; Mehran and Thakor, 2011) and therefore are more likely to lend funds to low-income borrowers. Does the increased equity help banks to lend more to low-income residents? Otherwise, do banks switch to high-income borrowers so as to better endure losses rendered by the upcoming disasters? The balance sheet structure, nonetheless, cannot tell us which effect is dominant. To explore this issue, we look at the lending preferences of banks in my next subsection.

\subsection{Lending Preferences}

\subsubsection{Borrower Income}

If banks with stronger experiences use their additional capital to enhance their monitoring, we expect to see a negative relationship between earthquake experiences and the average income of borrowers. But if disasters lead banks to be circumspect in lending, we expect a positive relationship. To explore which effect dominates, we rely on the HMDA dataset containing the yearly borrower income that we use as a proxy for borrower credit quality.

The results in Table 4 point to a significantly positive relationship between earthquake experiences and the borrower income, which means banks become more willingly to lend to borrowers with good credit quality after experiencing more earthquakes. The economic effect of this finding is significant: An increase rise of the disaster experience variable from its $10^{\text {th }}$ percentile to its $90^{\text {th }}$ percentile corresponds to an increase in average borrower income of 69 thousand dollars. ${ }^{15}$ Such a change in the borrower composition deserves due attention from policy makers: As will be elaborated in the later subsec-

\footnotetext{
${ }^{15}$ Note in this regression we did not include the dummies for counties for the following reasons: First, the county dummies do not have a strong economic interpretation because the experience variable is an aggregate of experiences of branches that are located across several counties. The "headquarter effects" in the previous analyses is merely a far-fetched interpretation; second, controlling for them leads to poorly fitted model with negative adjusted R-squared value, high p-value, and insignificant coefficients for all variables, including the constant. In this view, we dropped these dummies of ambiguous economic meanings. Another potential identification issue is that high-income consumers may select big, renowned banks. We handle this issue by excluding all banks with more than $\$ 2$ billion total assets in the robustness test. Inferences about the relation between bank risk taking and disaster experience continue to hold in this smaller sample.
} 
tion, in the past decades counties with higher earthquake risks have witnessed an inflow of low-income households and an outflow of rich families. By inducing banks to adjust their borrower composition, disasters impose credit restrictions on low-income people who come to rebuild cities undergoing costly damages (Elliott, 2014). Such an inefficiency in credit rationing can slowdown a recovery.

\subsubsection{Borrower Race}

Besides income levels, borrowers' racial composition is another measure of inequality. When banks have a subjective bias toward ethnic minorities, they may choose to reduce lending after being made more conservative by disaster experiences. And indeed, one of the purposes of the HMDA dataset is to monitor possibly discriminatory lending patterns in banks. As has been shown in the previous studies using the HMDA dataset, the inequality issue exists in the lending to different ethnic groups (Avery et al., 2005).

My results in Table 5, nevertheless, show that there is no link between earthquake experiences and the proportion of minority borrowers. Apparently, no news is good news. The results, however, should be generalized carefully because we am only examining banks in California, a state well known for its ethnic diversity.

\subsection{The Effects of Earthquake Experiences on Market Forces}

In the preceding part, we provide evidence showing the significant impact of earthquake experiences on banks' balance sheet structure and lending preferences. For the sake of generality, we address all the dependent variables as "risk-taking measures." But in fact, except for the capital ratio that is commonly used as a measure of bank risk taking (Collier, 2014; Bouwman and Malmendier, 2015; Thakor, 2014), both the real estate loan and borrower composition reflect to a great extent the external market forces. Notably, unlike individuals, banks need to absorb deposits from the market and are obliged to provide liquidity to support the economy. In this view, examining changes in the market forces associated with disaster experiences is not only compelling, but is also necessary. 


\subsubsection{Market Forces and the Real Estate Ratio}

For the banking sector, market forces inherently contain two elements: The supply of deposits and the demand for loans. In this subsection, we show that earthquake experiences lead to a shortfall in branch deposits, contributing to the decrease in the real estate ratio.

We obtain the deposit data from the SOD dataset of the FDIC. Now that the data are at the branch level, we no longer aggregate and can simply use equation (1) to construct the earthquake experience for each branch. The regression results on the impact of earthquake experiences on deposits are presented in column (i) of Table 6. The results show that branches with stronger earthquake experiences witness a significant decrease in their deposits. The economic magnitude of this differential effect is moderate: A change from the $10^{\text {th }}$ to the $90^{\text {th }}$ percentile of earthquake experiences is associated with a decrease in deposits of 314 thousand dollars in a bank branch. This finding confirms that the decrease in the real estate ratio is related the shortfall of deposits. ${ }^{16}$

But what are the reasons for the decline in deposits? Do economic and/or demographic conditions play a role? To find the answer, we examine the impact of earthquake experiences on the median household income of California counties. Exploring the countylevel income data nevertheless requires the construction of county-level experiences. The procedure is analogous except we now use the date of incorporation to represent the date of establishment of the county. ${ }^{17}$ The results indicate a significantly negative relationship between earthquake experience and household income. Based on the estimates reported in column (ii) of Table 6 , an increase in the earthquake experience from its $10^{\text {th }}$ percentile to its $90^{\text {th }}$ percentile implies a decrease in income of 51 dollars for each household. This finding shows that over the years, earthquakes have driven rich people to migrate out of the county and poor people to move in. The decrease of deposits is thus the consequence

\footnotetext{
${ }^{16}$ As savings determine banks' budget constraint, it is easy to understand that the deposit and the level of real estate loan are positively related. But the link between deposit and the ratio is less clear. To fulfill my logic circle, in Figure 4 in the appendix, we confirm a positive relationship between deposit and real estate ratio using a scatter plot. Therefore, as deposits drop, the ratio also decreases.

${ }^{17}$ In the current context, incorporation means that a county has legally become or formed to be a political entity of California.
} 
of the changes in the income structure. ${ }^{18}$

Disregarding the clear evidence above, one may be concerned that such a decrease in deposits is driven by the decrease of the overall population of the county, but not by the changes in income structure. We do not find this to be the case in my tests of the effects of experiences on migration. The results in column (iii) and (iv) of Table 6 show that the impact is neither significant for net migration nor for net domestic migration, thus allaying the concern of the decrease of the overall population being a confounding factor. Moreover, in line with the sociological literature on the relationship between natural hazards and residential mobility (Pais and Elliott, 2008; Schultz and Elliott, 2013), my results assert that disasters act both as an environmental "push" and "pull". Especially, rather than focusing on the immediate effects of disasters (Elliott, 2014; Pais and Elliott, 2008), we contribute to the literature by exploring the long-term effects of a series of events. So far we can conclude that disaster experiences cause wealthier people to migrate out of the county and poorer people to move in. In this way, low-income people increase their job opportunities by helping the recovery but at the cost of facing more future hazards.

As a complement, we examine whether the demand for loans are affected by natural disaster experiences using the HMDA data. The HMDA data provide the "loan amount" for every bank branch in the period 2010 to 2015. Again, the key explanatory variable is the county-level earthquake experience. We construct the dependent variable through averaging the loan amount across each bank's branches in every county. Results in column (v) of Table 6 indicate an insignificant relationship between the demand for loans and the earthquake experience, with a negative shape parameter. The effect remains insignificant even if we fix the shape parameter to a positive value (column (vi)). This finding further confirms that rebuilding activities do happen after disasters and thus stimulate the demand for loans. Further, as illustrated in the distribution map before, earthquakes are frequent in developed costal regions. Although they are prone to natural

\footnotetext{
${ }^{18}$ One reasonable concern is that higher income level may not lead to more bank deposit because, instead of saving, rich families can invest in various financial assets such as bonds, stocks, and mutual funds. To bridge the link between household income and deposit level, we draw a scatter plot in Figure 5 in the appendix. The figure confirms that high median household income is related to high deposit level.
} 
hazards, these regions have a strong ability of attracting various types of businesses, so the demands for funds are less likely to fall.

In sum, besides banks, markets and residents also learn from their disaster experiences. Specifically, rich families living in counties with stronger earthquake hazard learn from their experiences and migrate to safer places. Such change in the demographic structure consequently brings down the deposit level, contributing to the decrease in real estate loans of banks in those counties.

It is worth pausing a moment to reflect the channels linking disasters to bank decision making. In general, there are two routes: The first is the "learning from experience" channel that is psychological and relates to behavior finance; the second is the "market forces" channel that is more mechanical and has a general equilibrium taste. The special features of the banking sector determine the importance of these two channels. By absorbing and lending funds, banks interact closely with local markets, and their practices largely reflect the market conditions. Thus, while disasters can alter the risk attitude of banks, they can also change the market conditions, especially in the long-term. Therefore, while papers on individual decision-making can easily reach the conclusion that disasters affect the risk attitudes of investors through the "learning channel" (Malmendier and Nagel, 2011, 2015; Bernile et al., 2017), my paper must carefully evaluate both channels. So far, though we have pointed out the role of market forces in affecting the real estate ratio, we cannot exclude the learning channel because doing so will require specific data such as surveys of bankers. Therefore, the conclusion is that both channels can exist. However, as is discussed in the next subsection, we validate the "learning" channel in the change of borrower income by showing that market forces play no role.

\subsubsection{Market Forces and the Borrower Income}

In the previous subsection, we find banks with stronger earthquake experiences tend to lend to high-income borrowers. At that moment we resisted the temptation of concluding that banks are made conservative by their disaster experiences, for the change in borrower composition may be related to the change in local income structure. Indeed, by exploring the market forces, we find that counties with higher earthquake hazards witness a decrease in median household income. Nevertheless, in line with the "market forces" channel we 
may still be concerned that banks follow high-income borrowers to "migrate" (i.e. switch their activities) to less hazardous regions. This hypothesis is easy to reject.

Results in Table 6 already show that counties with stronger earthquake experiences do not witness a decrease in loan demand. In this subsection, we go a step further by examining what types of loans are likely to happen in less hazardous counties. Doing so naturally requires the binary choice regression model. Specifically, we use the HMDA data and denote 1 if the county is in the less hazardous region, as defined in Section 2, and 0 otherwise. The three loan characters are loan amount, borrower income, and borrower race. Results shown in Table 7 are based on the linear probability model, the probit model, and the logit model respectively. ${ }^{19}$

The results point out a significantly negative relationship between the county indicator and the loan amount and a significantly positive relationship between the county indicator and the borrower income. Thus, although high-income borrowers are more likely to live in less risky counties, they do not necessarily borrow more. On the contrary, it is the more hazardous (costal) regions that demand more loans to support their economic development. Last but not least, the results in Table 7 resonate with my previous findings that low-income borrowers migrate to riskier regions. For example, besides showing that rich people concentrate in less hazardous regions, the significantly negative coefficients for "nonwhite applicant" also indicate that nonwhite residents tend to live in disaster-prone regions.

In short, this subsection excludes the link between market forces and the borrower income level of banks. At this moment, we can confirm that the increase in borrower income for banks with stronger earthquake experiences is because these banks have become more conservative after learning from their experiences.

\footnotetext{
${ }^{19}$ Estimates in columns (ii) to (vii) are based on the randomly selected subsamples (1\% full sample) because the huge number of observations in the full sample implies too few variations in the data and prevents the probit and logit models from converging. To show that the results are robust to the selection of subsamples, we run three regressions for each probit and logit model.
} 


\subsection{Robustness}

In this subsection, we carry out a series of tests to evaluate the robustness of my baseline analyses and basic inferences.

\subsubsection{Different Thresholds for Selecting Earthquakes}

The first robustness test is related to the concern about the ad hoc threshold used for selecting earthquakes. As discussed in Section 2, an earthquake is included in my sample for the baseline analyses if it has a magnitude no less than 4, which means that we implicitly posit that banks ignore earthquakes weaker than this magnitude. To ensure the robustness of my major inferences, in Table 8, we estimate the models using two different thresholds (magnitude $=2.5$ and 5 ), which presumes that banks ignore earthquakes weaker than 2.5 (and 5). ${ }^{20}$ To save the time of estimation, we fix the values of the shape parameters at their previously estimated values in column (iii)'s of Tables 2, 3, and 4.

The results in Table 8 are largely congruent with the results in my baseline analyses. First, the differential effects remain unchanged. For example, the results indicate that a spread between the $10^{\text {th }}$ and the $90^{\text {th }}$ percentile of disaster experiences generates a change in real estate ratio of about 2 percent. Second, the results imply that a one standard deviation increase in the earthquake experience is associated with a decrease in real estate ratio of about 1 percent. ${ }^{21}$ The results, however, are distinct in terms of their values of the coefficient $\beta$ : As the threshold rises, the coefficient value also increases significantly. This evidence is attributed to the construction of the experience variable: As the threshold rises, the branch-level experience becomes zero for weaker earthquakes and the distribution of the experiences becomes more concentrated. The value of the estimate therefore increases.

\footnotetext{
${ }^{20} \mathrm{By}$ choosing the threshold=2.5, we effectively include all earthquakes in my data, for 2.5 is the lowest magnitude in the USGS dataset. According to the description on the USGS website, earthquakes with magnitudes between 1.0 and 3.0 are not felt except by a very few under especially favorable conditions.

${ }^{21}$ The effects of "one standard deviation in experience" are evaluated during running the programs and are not reported.
} 


\subsubsection{High-Income Borrowers Prefer Large Banks}

In my baseline analyses, we show that banks having stronger disaster experiences tend to extend their funds to high-income borrowers. This conclusion, however, can be discredited by a potential reverse-causality problem: In order to obtain more advanced financial services, high-income borrowers are likely to choose large banks. These banks have stronger earthquake experiences due to their large number of branches and long operating histories. This mechanism could lead to spurious effects of banks' disaster experiences on the borrower income level.

We address such concern in two ways. First, my previous tests control for the bank size variables (e.g. total assets and number of branches). Since these controls are highly positively correlated with the experience variables, by including them, we largely mitigate the omitted-variable problem. Second, to further allay the reverse-causality concern, we exclude all banks with assets above $\$ 2$ billion from my sample. The results presented by Table 9 show that my main inferences are unchanged.

\subsubsection{Rescale the Magnitude}

In my earthquake data, the Richter Scale is used to measure the magnitudes of earthquakes. It is a base-10 logarithmic scale. For example, an earthquake with a magnitude of 5 has a shaking amplitude ten times greater than an earthquake of magnitude 4 . In the previous analyses, for simplicity reason, we treated the scale to be linear. In this robustness test, we rescale the magnitudes by taking the natural and base-10 exponentials for magnitudes respectively. Panel A and B in Table 10 report the results. By fixing the shaping parameter values, the differential effects remain intact in Panel A while almost halves in Panel B. ${ }^{22}$

\footnotetext{
${ }^{22}$ Please notice that in this robustness check, we fix the values of the shaping parameters. As taking the base-10 exponentials can greatly increase the magnitude of bigger earthquakes, the actual shaping parameters are likely to be smaller. For example, when the shaping parameter in the real estate ratio regression is 0.05 instead of 0.18 , then the differential effect becomes -0.037 .
} 


\subsection{Can Disasters Make Banks More Risk-Loving?}

Thus far, we have shown that stronger disaster experiences lead banks to reduce the real estate loan level, boost their capital adequacy, and lend to high-income borrowers. These relationships, however, are implicitly presumed to be monotonic. But one might suspect that banks that continuously survive from moderate disasters may believe that they are resilient to adverse events and thus become overconfident. This concern echoes with the recent findings by Bernile et al. (2017) who show that CEOs with moderate earlylife natural disaster experiences are more willing to make riskier financial decisions than CEOs whose experiences are at the low and high extremes. To explore such a dimension of heterogeneity in the banking sector, we classify banks into ten groups by the deciles of their earthquake experiences and analyze each subsample, fixing the shape parameter $\lambda$ at their previously estimated values. Figure 3 shows the estimated effects of earthquakes $(\beta)$ and their $t$-statistics for each decile group.

The figure demonstrates a few things. Specifically, we find banks who are the least exposed to earthquakes tend to extend a significantly larger amount of real estate loans and maintain a lower level of capital. For instance, for banks in the bottom decile group, increasing the experience from its $10^{\text {th }}$ percentile to its $90^{\text {th }}$ percentile leads to a decrease in capital ratio of about 1.1 percent. Given that the standard deviation of the capital ratio is 2.8 percent for these banks, the economic magnitude is sizable. This means that banks that experienced very few fatal disasters are more risk-loving than banks whose disaster experiences are stronger. However, as the earthquake experiences accumulate, banks reduce their real estate loans, increase the capital adequacy, and finally invert the relationship. In contrast to Bernile et al. (2017), my plots show an almost monotonic relationship between disaster experiences and measures of bank risk taking. These two pieces of evidence are not easily compared because the samples and the measures of disaster experiences are so different. But at least both indicate that the beliefs of decision-makers about future risks depend heavily on the disaster intensity. 


\section{Conclusion}

This paper studies the relationship between disaster experiences and the business practices of banks. California offers an ideal setting for identification. It has a comprehensive record of earthquakes dating back to the 18th century and its socio-economic variables are easy to access. Exploiting the completeness of the data, we manage to identify the longterm impacts of disaster experiences on balance sheet structure and lending preference and to explore the evolution of market forces underlying such changes.

We find banks with bigger earthquake exposures throughout their lives tend to issue less real estate loans, increase the equity level, and are more likely to lend to high-income borrowers. My empirical results show that an increase in the earthquake experience from its $10^{\text {th }}$ percentile to its $90^{\text {th }}$ percentile leads to a decrease in real estate ratio of about 3.1 percent and an increase in average borrower income of around 69 thousand dollars. Fortunately we do not find evidence that strong earthquake experiences lead banks to become more discriminated against ethnic minorities.

Banks interact closely with local markets, so both the subjective risk taking and the external market forces determine their loan quantity and borrower composition. With the assistance of my detailed data, we confirm that both channels exist. First, counties that frequently experience earthquakes in their history witness an outflow (inflow) of rich (poor) households and consequently a decrease in income level. As a result, deposits in bank branches drop, tightening the budget constraint and contributing to the shrinkage in risky loans. These results thus point to a general equilibrium channel. Second, despite that rich families migrate to risk-prone counties, banks did not follow on to switch their activities. As a matter of fact, most lending activities concentrate in riskier regions, perhaps due to the strong demand for funds of the costal area. The increased borrower income therefore is not led by changes in market forces but is mostly related to banks learning from disaster experiences.

My main results remain stable under a battery of robustness tests. In particular, the test designed to explore the heterogeneous effects of disaster experiences reveals that banks with extremely small disaster exposure become risk-loving. But as experiences accumulate, the dependent variables alter monotonically and the risk attitude inverts. 
Though my results are robust and statistically significant, the economic magnitude is on average modest. This is not necessarily a defect as we have pointed out and tested the various forces, many of which are in opposite direction, that drive my measures of balance sheet structure and lending preferences. Meanwhile, when we calculate the differential effects using the maximum and minimum values of the experience, the economic magnitude appears large. Since disasters are highly unevenly distributed over the world, the effects of disaster experiences on financial systems of different countries will be non-negligible.

Finally, the positive yet near-zero values of the shape parameter imply an almost flat memorizing curve of disasters. Therefore, even shocks happened far back in the past do not fade away easily and still influence current financial decisions. Moreover, compared with the values of the shape parameter estimated in Malmendier and Nagel (2011, 2015), those in my paper are even lower, indicating that institutions retain longer memories than individuals do. In view of the long-lasting effect of shocks and the intermediate role of the banking sector, building a general equilibrium learning model to account for the long-term influence of disasters is a tenable future endeavor. 


\section{References}

Avery, R. B., Canner, G. B., and Cook, R. E. (2005), "New information reported under HMDA and its application in fair lending enforcement," Fed. Res. Bull., 91, 344.

Berg, G. and Schrader, J. (2012), "Access to credit, natural disasters, and relationship lending," Journal of Financial Intermediation, 21, 549-568.

Berger, A. N. and Bouwman, C. H. (2013), "How does capital affect bank performance during financial crises?" Journal of Financial Economics, 109, 146-176.

Bernile, G., Bhagwat, V., and Rau, P. R. (2017), "What doesn't kill you will only make you more risk-loving: Early-life disasters and CEO behavior," The Journal of Finance, $72,167-206$.

Bouwman, C. H. and Malmendier, U. (2015), "Does a bank's history affect its risktaking?" The American Economic Review, 105, 321-325.

Chavaz, M. (2014), "Riders of the storm: Economic shock \& bank lending in a natural experiment," Working paper, Bank of England. Available at: https://www.rsm.nl/fileadmin/home/Department_of_Finance__VG5_ /ECC2014/Final_Papers/Chavaz.pdf.

Cole, R. A. and White, L. J. (2012), "Déjà vu all over again: The causes of US commercial bank failures this time around," Journal of Financial Services Research, 42, 5-29.

Collier, B. (2014), "Natural disasters and credit supply shocks," Working Paper, University of Pennsylvania. Available at: http://opim.wharton. upenn.edu/risk/library/ WP201402_BLC_Disasters+CreditSupply ·pdf.

Collier, B., Katchova, A. L., and Skees, J. R. (2011), "Loan portfolio performance and El Niño, an intervention analysis," Agricultural Finance Review, 71, 98-119.

Cortés, K. R. and Strahan, P. E. (2017), "Tracing out capital flows: How financially integrated banks respond to natural disasters," Journal of Financial Economics. 
Dell'Ariccia, G., Laeven, L., and Suarez, G. A. (2016), "Bank leverage and monetary policy's risk-taking channel: Evidence from the United States," The Journal of Finance.

Elliott, J. R. (2014), "Natural hazards and residential mobility: General patterns and racially unequal outcomes in the United States," Social Forces, 93, 1723-1747.

Holmstrom, B. and Tirole, J. (1997), "Financial intermediation, loanable funds, and the real sector," The Quarterly Journal of Economics, 112, 663-691.

Hott, C. (2011), "Lending behavior and real estate prices," Journal of Banking $\&$ Finance, $35,2429-2442$.

King, R. G. and Levine, R. (1993), "Finance, entrepreneurship and growth," Journal of Monetary Economics, 32, 513-542.

Klomp, J. (2014), "Financial fragility and natural disasters: An empirical analysis," Journal of Financial Stability, 13, 180-192.

Lambert, C., Noth, F., and Schüwer, U. (2015), "How do banks react to catastrophic events? Evidence from Hurricane Katrina," Working paper, Goethe University Frankfurt. Available at: https://ssrn. com/abstract=2585521.

Levine, R. (1997), "Financial development and economic growth: Views and agenda," Journal of Economic Literature, 35, 688-726.

Malmendier, U. and Nagel, S. (2011), "Depression babies: Do macroeconomic experiences affect risk taking?" The Quarterly Journal of Economics, 126, 373-416.

- (2015), "Learning from inflation experiences," The Quarterly Journal of Economics, $131,53-87$.

Mehran, H. and Thakor, A. (2011), "Bank capital and value in the cross-section," The Review of Financial Studies, 24, 1019-1067.

Pagano, M. (1993), "Financial markets and growth: An overview," European Economic Review, 37, 613-622. 
Pais, J. F. and Elliott, J. R. (2008), "Places as recovery machines: Vulnerability and neighborhood change after major hurricanes," Social Forces, 86, 1415-1453.

Schultz, J. and Elliott, J. R. (2013), "Natural disasters and local demographic change in the United States," Population and Environment, 34, 293-312.

Stover, C. W. and Coffman, J. L. (1993), Seismicity of the United States, 1568-1989 (revised), US Government Printing Office.

Thakor, A. V. (2014), "Bank capital and financial stability: An economic trade-off or a Faustian bargain?" Annu. Rev. Financ. Econ., 6, 185-223. 


\section{Table 1: Key Statistics}

This table summarizes descriptive statistics for the variables used in my baseline regressions. The sample includes my four measures of bank risk taking. The capital ratio and real estate loan ratio are based on Call Report data from 1994Q1 to 2013Q4. They measure risk taking from the perspective of balance sheet structure. The borrower income and borrower race are based on HMDA data from 2010 to 2013. They measure risk taking from the aspect of bank lending preference. Branch deposit and branch number are from the Summary of Deposits of FDIC. NonHaz branch\% indicates the proportion of branches of a bank in counties less prone to earthquakes. Bank age is the age of the headquarter bank. Poverty data are from the U.S. Census Bureau. Unemployment rate and population are from websites of the California government. Panel A includes data for all banks. To exclude the effects of big banks, Panel B restricts the sample to banks with less than or equal to 3 branches.

\begin{tabular}{|c|c|c|c|c|c|}
\hline & Average & $\begin{array}{l}\text { Standard } \\
\text { Deviation }\end{array}$ & $\begin{array}{c}10^{\text {th }} \\
\text { Percentile }\end{array}$ & $\begin{array}{c}90^{\text {th }} \\
\text { Percentile }\end{array}$ & Observations \\
\hline \multicolumn{6}{|l|}{ Panel A: Full Sample } \\
\hline \multicolumn{6}{|l|}{ Bank variables } \\
\hline Real estate loan ratio & 0.440 & 0.179 & 0.216 & 0.669 & 20368 \\
\hline Capital ratio & 0.127 & 0.112 & 0.070 & 0.185 & 19334 \\
\hline Borrower income ( $\$$ thousands) & 320.688 & 379.76 & 90 & 705.63 & 307 \\
\hline Borrower race\% & 0.218 & 0.325 & 0 & 0.903 & 307 \\
\hline Total assets ( $\$$ billions) & 2.744 & 36.750 & 0.044 & 1.375 & 20368 \\
\hline $\mathrm{ROA}$ & 0.027 & 0.016 & 0.010 & 0.047 & 19817 \\
\hline Imputed Rate Total & 0.170 & 6.514 & 0.023 & 0.119 & 19650 \\
\hline ImputedInt Rate RE Loan & 0.044 & 0.048 & 0.016 & 0.074 & 13190 \\
\hline Deposit ( $\$$ millions $)$ & 72.044 & 338.996 & 17.567 & 110.597 & 5181 \\
\hline Bank age (years) & 21.108 & 24.202 & 2.778 & 40.844 & 20368 \\
\hline NonHaz branch\% & 0.090 & 0.262 & 0 & 0.333 & 20021 \\
\hline Branch number & 13.257 & 71.547 & 1 & 15 & 20021 \\
\hline \multicolumn{6}{|l|}{ Regional variables } \\
\hline Unemployment\% & 9.136 & 0.045 & 5.7 & 11.6 & 4640 \\
\hline Poverty $\%$ & 14.672 & 4.956 & 10.8 & 18.1 & 1102 \\
\hline Population (thousands) & 606 & 1365 & 45 & 620 & 1160 \\
\hline \multicolumn{6}{|c|}{ Panel B: Banks with Branch Number $\leq 3$} \\
\hline \multicolumn{6}{|l|}{ Bank variables } \\
\hline Real estate loan ratio & 0.430 & 0.187 & 0.185 & 0.661 & 10751 \\
\hline Capital ratio & 0.142 & 0.130 & 0.070 & 0.224 & 10522 \\
\hline Borrower income ( $\$$ thousands) & 376.638 & 443.424 & 84 & 893.833 & 139 \\
\hline Borrower race $\%$ & 0.190 & 0.328 & 0 & 0.9 & 139 \\
\hline Total assets ( $\$$ billions) & 0.220 & 1.256 & 0.035 & 0.268 & 10751 \\
\hline $\mathrm{ROA}$ & 0.027 & 0.015 & 0.010 & 0.046 & 10469 \\
\hline Imputed Rate Total & 0.152 & 3.041 & 0.024 & 0.124 & 10311 \\
\hline ImputedInt Rate RE Loan & 0.043 & 0.066 & 0.016 & 0.069 & 6103 \\
\hline Deposit (\$ millions) & 78.524 & 444.127 & 15.705 & 120.835 & 2748 \\
\hline Bank age (years) & 12.414 & 13.361 & 1.704 & 24.008 & 10751 \\
\hline NonHaz branch $\%$ & 0.071 & 0.250 & 0 & 0 & 10751 \\
\hline Branch number & 1.852 & 0.804 & 1 & 3 & 10751 \\
\hline
\end{tabular}




\section{Table 2: Disaster Experiences Decrease Banks' Exposure to Real Estate}

This table reports regression estimates of real estate ratios from 1994Q1 to $2013 \mathrm{Q} 4$ on earthquake experiences of banks and a variety of banking and regional variables (poverty percent, population, and unemployment rate). The real estate ratio is based on Call Reports and is defined as the proportion of a bank's real estate loan to its total assets. The regional variables control for the macroeconomic and demographic conditions of counties that can affect the demand for real estate loans. The poverty percent, population, and unemployment rate are from the U.S. Census Bureau, the Employment Development Department of California, and the Department of Finance of California respectively. We estimate the model on a tightly spaced grid of values of the weighting parameter $\lambda(\mathrm{step}=0.02)$, and select the estimates resulting in the lowest residual sum of squares to be the final estimated coefficients. The standard errors robust to heteroscedasticity are reported in parentheses. The weighting parameters are shown in the first row. All the regressions control for year fixed effects.

\begin{tabular}{|c|c|c|c|}
\hline & (i) & (ii) & (iii) \\
\hline Weighting parameter $\lambda$ & 0.26 & 0.18 & 0.18 \\
\hline Earthquake experience coefficient $\beta$ & $\begin{array}{l}-0.219 \\
(0.017)\end{array}$ & $\begin{array}{l}-0.218 \\
(0.017)\end{array}$ & $\begin{array}{l}-0.219 \\
(0.017)\end{array}$ \\
\hline NonHaz branch\% & & $\begin{array}{l}-0.110 \\
(0.020)\end{array}$ & $\begin{array}{l}-0.107 \\
(0.020)\end{array}$ \\
\hline Branch number & & & $\begin{array}{r}1.017 \times 10^{-5} \\
\left(2.028 \times 10^{-5}\right)\end{array}$ \\
\hline Bank-level controls & Yes & Yes & Yes \\
\hline Regional controls & Yes & Yes & Yes \\
\hline Headquarter fixed effects & Yes & Yes & Yes \\
\hline Year fixed effects & Yes & Yes & Yes \\
\hline $\begin{array}{l}\text { Average of actual value at } 90^{\text {th }} \text { pct. minus actual value } \\
\text { at } 10^{\text {th }} \text { pct. of earthquake experience }\end{array}$ & -0.031 & -0.031 & -0.031 \\
\hline $\begin{array}{l}\text { Average of fitted value at maximum minus fitted value } \\
\text { at minimum of earthquake experience }\end{array}$ & -0.461 & -0.458 & -0.461 \\
\hline$R$-squared & 0.481 & 0.476 & 0.474 \\
\hline Observations & 10625 & 10597 & 10545 \\
\hline Number of banks & 415 & 415 & 415 \\
\hline
\end{tabular}




\section{Table 3: Disaster Experiences Boost Banks' Capital Adequacy}

This table reports results of estimating regressions of bank capital ratios from 1994Q1 to $2013 \mathrm{Q} 4$ on earthquake experiences and a variety of bank-specific variables (total assets, ROA, imputed interest rate, real estate loan, portion of branches in less hazardous regions, number of branches, and bank age). The dependent variable, capital ratio, is based on Call Reports. It equals the ratio of total equity to GTA, where GTA is total assets plus the allowance for loan and lease losses plus the allocated transfer risk reserve. Data for bank branches are from the SOD dataset of FDIC. To construct the earthquake experience variable for each bank, we match the earthquakes and bank branches by their counties of occurrence/location and then aggregate branch-level experiences to bank-level experiences based on the deposit amounts of branches. All other bank variables are from the Call Reports. All other variables are as defined in Table 2. We estimate the model on a tightly spaced grid of values of the weighting parameter $\lambda(\operatorname{step}=0.02)$, and select the estimates resulting in the lowest residual sum of squares to be the final estimated coefficients. The standard errors robust to heteroscedasticity are reported in parentheses. The weighting parameters are shown in the first row. The NonHaz branch\% and Branch number are of identification importance and are thus tabulated explicitly. All the regressions control for year fixed effects.

\begin{tabular}{|c|c|c|c|}
\hline & (i) & (ii) & (iii) \\
\hline Weighting parameter $\lambda$ & 0.24 & 0.30 & 0.28 \\
\hline \multirow[t]{2}{*}{ Earthquake experience coefficient $\beta$} & 0.008 & 0.006 & 0.007 \\
\hline & $(0.001)$ & $(0.001)$ & $(0.001)$ \\
\hline \multirow[t]{2}{*}{ NonHaz branch\% } & & 0.011 & 0.012 \\
\hline & & $(0.004)$ & $(0.004)$ \\
\hline \multirow[t]{2}{*}{ Branch number } & & & $9.476 \times 10^{-5}$ \\
\hline & & & $\left(3.434 \times 10^{-5}\right)$ \\
\hline Bank-level controls & Yes & Yes & Yes \\
\hline Headquarter fixed effects & Yes & Yes & Yes \\
\hline Year fixed effects & Yes & Yes & Yes \\
\hline Average of actual value at $90^{\text {th }}$ pct. minus actual value & 0.002 & 0.002 & 0.002 \\
\hline \multicolumn{4}{|l|}{ at $10^{\text {th }}$ pct. of earthquake experience } \\
\hline Average of fitted value at maximum minus fitted value & 0.046 & 0.046 & 0.046 \\
\hline \multicolumn{4}{|l|}{ at minimum of earthquake experience } \\
\hline$R$-squared & 0.240 & 0.238 & 0.237 \\
\hline Observations & 16473 & 16473 & 16473 \\
\hline Number of banks & 464 & 464 & 464 \\
\hline
\end{tabular}




\section{Table 4: Disaster Experiences Trigger Flight-to-Quality of Banks}

This table reports estimates of regressions of the income of borrowers on earthquake experiences of banks and a series of bank- and regional-specific variables. The time horizon is 2010 to 2013. We first collect the income of individual borrowers from the HMDA dataset and then calculate the yearly average of the borrower income for each bank and use it as the dependent variable. All other explanatory variables are as defined in Table 2. We estimate the model on a tightly spaced grid of values of the weighting parameter $\lambda(\mathrm{step}=0.02)$, and select the estimates resulting in the lowest residual sum of squares to be the final estimated coefficients. The standard errors robust to heteroscedasticity are reported in parentheses. The weighting parameters are shown in the first row. All the regressions control for year fixed effects.

\begin{tabular}{|c|c|c|c|}
\hline & (i) & (ii) & (iii) \\
\hline Weighting parameter $\lambda$ & 1.16 & 1.16 & 1.24 \\
\hline \multirow[t]{2}{*}{ Earthquake experience coefficient $\beta$} & 602.318 & 657.936 & 592.535 \\
\hline & $(250.450)$ & $(269.318)$ & $(252.941)$ \\
\hline \multirow[t]{2}{*}{ NonHaz branch\% } & & 53.658 & 56.862 \\
\hline & & $(55.099)$ & $(56.967)$ \\
\hline \multirow[t]{2}{*}{ Branch number $\%$} & & & -1.511 \\
\hline & & & $(2.028)$ \\
\hline Bank-level controls & Yes & Yes & Yes \\
\hline Regional controls & Yes & Yes & Yes \\
\hline Year fixed effects & Yes & Yes & Yes \\
\hline Average of fitted value at $90^{\text {th }}$ pct. minus fitted value & 65.866 & 71.948 & 68.832 \\
\hline \multicolumn{4}{|l|}{ at $10^{\text {th }}$ pct. of earthquake experience } \\
\hline Average of fitted value at maximum minus fitted value & 368.857 & 402.917 & 390.313 \\
\hline \multicolumn{4}{|l|}{ at minimum of earthquake experience } \\
\hline$R$-squared & 0.193 & 0.189 & 0.178 \\
\hline Observations & 280 & 280 & 280 \\
\hline Number of banks & 112 & 112 & 112 \\
\hline
\end{tabular}




\section{Table 5: No Significant Impact on Borrower Race}

This table reports estimates of regressions of the portion of non-white borrowers on earthquake experiences of banks and a series of bank- and regional-specific variables. The time horizon is 2010 to 2013 . We first collect the information of borrower race from the HMDA dataset and then calculate the portion of non-white borrowers for each bank and use it as the dependent variable. All other explanatory variables are as defined in Table 2. We estimate the model on a tightly spaced grid of values of the weighting parameter $\lambda(\mathrm{step}=0.02)$, and select the estimates resulting in the lowest residual sum of squares to be the final estimated coefficients. The standard errors robust to heteroscedasticity are reported in parentheses. The weighting parameters are shown in the first row. All the regressions control for year fixed effects.

\begin{tabular}{|c|c|c|c|}
\hline & (i) & (ii) & (iii) \\
\hline Weighting parameter $\lambda$ & -0.04 & -0.12 & -0.12 \\
\hline Earthquake experience coefficient $\beta$ & $\begin{array}{l}-0.270 \\
(0.474)\end{array}$ & $\begin{array}{l}-0.232 \\
(0.555)\end{array}$ & $\begin{array}{l}-0.301 \\
(0.581)\end{array}$ \\
\hline NonHaz branch $\%$ & & $\begin{array}{c}0.008 \\
(0.044)\end{array}$ & $\begin{array}{c}0.008 \\
(0.045)\end{array}$ \\
\hline Branch number\% & & & $\begin{array}{l}-0.001 \\
(0.002)\end{array}$ \\
\hline Bank-level controls & Yes & Yes & Yes \\
\hline Regional controls & Yes & Yes & Yes \\
\hline Year fixed effects & Yes & Yes & Yes \\
\hline $\begin{array}{l}\text { Average of fitted value at } 90^{\text {th }} \text { pct. minus fitted value } \\
\text { at } 10^{\text {th }} \text { pct. of earthquake experience }\end{array}$ & -0.012 & -0.010 & -0.014 \\
\hline $\begin{array}{l}\text { Average of fitted value at maximum minus fitted value } \\
\text { at minimum of earthquake experience }\end{array}$ & -0.052 & -0.041 & -0.053 \\
\hline$R$-squared & 0.510 & 0.479 & 0.464 \\
\hline Observations & 280 & 280 & 280 \\
\hline Number of banks & 112 & 112 & 112 \\
\hline
\end{tabular}


Table 6: The Effects of Earthquake Experiences on Deposits, Demographics, and Loan Demands

This table reports the effects of earthquake experiences on branch deposit, median household income, net migration, net domestic migration, and branch average loan amount respectively. The time horizon is 1994 to 2013 for the first four variables and 2010 to 2015 for the last variable. The purpose of this table is to explore the channel between the real estate loans and the supply/demand of funds of banks. The branch deposit is from the SOD dataset and represents the amount of deposit for each bank branch. The three demographic variables are at the county level. Median household income is from the U.S. Census Bureau. Net migration and net domestic migration are from the Department of Finance of California. The loan amount variable is at the bank-county level; the data come from the HMDA. The estimation method is as explained in the previous regressions. The standard errors reported in column (i) are robust to heteroscedasticity. Using robust errors for other regressions will cause Matlab to report problem message (iteration limit); this is because the values of some the explain variables are too close to each other. Since the standard errors for the insignificant $\beta$ 's are so large that they will remain so even if we scale the data and apply the robust errors, we simply use the non-robust standard errors for these regressions. The weighting parameters are shown in the first row. All the regressions control for county fixed effects and year fixed effects.

\begin{tabular}{|c|c|c|c|c|c|c|}
\hline & $\begin{array}{l}\text { Branch } \\
\text { Deposit }\end{array}$ & $\begin{array}{l}\text { Median } \\
\text { Income }\end{array}$ & $\begin{array}{l}\text { Net } \\
\text { Migration }\end{array}$ & $\begin{array}{l}\text { Net Domestic } \\
\text { Migration }\end{array}$ & \multicolumn{2}{|c|}{$\begin{array}{l}\text { HMDA Loan } \\
\text { Amount }\end{array}$} \\
\hline & (i) & (ii) & (iii) & (iv) & (v) & (vi) \\
\hline Weighting parameter $\lambda$ & 1.60 & 4.06 & 1.54 & 3.54 & -1.62 & $\begin{array}{c}2.0 \\
{[\text { fixed }]}\end{array}$ \\
\hline Experience coefficient $\beta$ & $\begin{array}{l}-0.430 \\
(0.105)\end{array}$ & $\begin{array}{l}-0.900 \\
(0.530)\end{array}$ & $\begin{array}{c}14.258 \\
(18.398)\end{array}$ & $\begin{array}{c}2.397 \\
(2.961)\end{array}$ & $\begin{array}{c}-71.520 \\
(364.128)\end{array}$ & $\begin{array}{c}0.155 \\
(2.790)\end{array}$ \\
\hline Branch-level controls & Yes & - & - & - & - & - \\
\hline Regional controls & Yes & Yes & Yes & Yes & Yes & Yes \\
\hline County fixed effects & Yes & Yes & Yes & Yes & Yes & Yes \\
\hline Year fixed effects & Yes & Yes & Yes & Yes & Yes & Yes \\
\hline $\begin{array}{l}\text { Difference in fitted value at } 90^{\text {th }} \\
\text { and at } 10^{\text {th }} \text { pct. }\end{array}$ & -0.314 & -0.051 & 0.615 & 0.129 & -0.005 & 0.006 \\
\hline $\begin{array}{l}\text { Difference in fitted value at max } \\
\text { and at } \min \end{array}$ & -42.714 & -4.181 & 6.423 & 6.770 & -0.634 & 0.015 \\
\hline Number of branches & 2960 & & & & & \\
\hline Number of banks & 549 & & & & 35 & 35 \\
\hline$R$-squared & 0.077 & 0.966 & 0.478 & 0.738 & 0.539 & 0.539 \\
\hline Observations & 33576 & 1057 & 1057 & 1057 & 220 & 220 \\
\hline
\end{tabular}




\section{Table 7: Banks Did Not Increase Lending in Less Hazardous Regions}

This table reports results of estimating binary choice regressions of "NonHaz" Region from 2010 to 2015. All variables are from the HMDA dataset. The dependent variable is an indicator equal to 1 if the county is in the less hazardous region, as defined in Section 2, and 0 otherwise. Loan amount is the dollar amount granted to an individual loan applicant by a bank branch; nonwhite applicant is an indicator variable equal to 1 if the loan applicant is nonwhite; and applicant income is the yearly income of the borrower. We use the linear probability model, the probit model, and the logit model. Column (i) reports results of the linear probability model based on the full sample. Estimates in the rest of the columns are based on the randomly selected subsamples (1\% full sample) because the huge number of observations in the full sample implies too few variations in the data and prevents the probit and logit models from converging. For each probit and logit model, we run three regressions to show that the results are robust to the selection of subsamples. The standard errors robust to heteroscedasticity are reported in parentheses. All the regressions control for the year fixed effects.

\begin{tabular}{|c|c|c|c|c|c|c|c|}
\hline & \multirow{2}{*}{$\begin{array}{c}\text { Linear } \\
\text { (i) }\end{array}$} & \multicolumn{3}{|c|}{ Probit } & \multicolumn{3}{|c|}{ Logit } \\
\hline & & (ii) & (iii) & (iv) & $(\mathrm{v})$ & (vi) & (vii) \\
\hline \multirow[t]{2}{*}{ Loan amount } & -0.137 & -2.350 & -2.436 & -2.251 & -4.943 & -4.809 & -4.663 \\
\hline & $(0.001)$ & $(0.071)$ & $(0.078)$ & $(0.084)$ & $(0.131)$ & $(0.145)$ & $(0.134)$ \\
\hline \multirow[t]{2}{*}{ Applicant income } & 0.020 & 0.078 & 0.118 & 0.188 & 0.266 & 0.144 & 0.001 \\
\hline & $(0.001)$ & $(0.068)$ & $(0.063)$ & $(0.061)$ & $(0.112)$ & $(0.161)$ & $(0.101)$ \\
\hline \multirow[t]{2}{*}{ Nonwhite applicant } & -0.022 & -0.117 & -0.085 & -0.075 & -0.124 & -0.209 & -0.155 \\
\hline & $(0.000)$ & $(0.022)$ & $(0.021)$ & $(0.021)$ & $(0.042)$ & $(0.043)$ & $(0.042)$ \\
\hline Year fixed effects & Yes & Yes & Yes & Yes & Yes & Yes & Yes \\
\hline$R$-squared & 0.023 & 0.078 & 0.081 & 0.071 & 0.081 & 0.079 & 0.076 \\
\hline Observations & $4,249,491$ & 42,495 & 42,495 & 42,495 & 42,495 & 42,495 & 42,495 \\
\hline
\end{tabular}




\section{Table 8: Robustness: Changing the Thresholds for Selecting Earthquakes}

This table reports estimates of regressions of dependent variables (given in column titles) using the fully specified models in Tables 2, 3, and 4. To reduce the estimation time, we fix the shape parameter $\lambda$ at their previous values estimated with the full specifications. In Panel A, we include earthquakes with magnitudes greater or equal to 2.5. In Panel B, we confine the earthquake sample to events with magnitudes greater or equal to 5. All corresponding controls and fixed effects from Tables 2, 3, and 4 are included by not shown for brevity. The standard errors robust to heteroscedasticity are reported in parentheses.

\begin{tabular}{|c|c|c|c|}
\hline & Capital ratio & Real estate ratio & Borrower income \\
\hline & (i) & (ii) & (iii) \\
\hline \multicolumn{4}{|l|}{ Panel A: Magnitude $\geq 2.5$} \\
\hline Weighting parameter $\lambda$ & $\begin{array}{c}0.28 \\
{[\text { fixed }]}\end{array}$ & $\begin{array}{c}0.18 \\
{[\text { fixed] }}\end{array}$ & $\begin{array}{c}1.24 \\
{[\text { fixed] }}\end{array}$ \\
\hline Earthquake experience coefficient $\beta$ & $\begin{array}{l}3.325 \times 10^{-4} \\
(0.000)\end{array}$ & $\begin{array}{l}-0.010 \\
(0.001)\end{array}$ & $\begin{array}{c}32.072 \\
(12.155)\end{array}$ \\
\hline $\begin{array}{l}\text { Average of actual value at } 90^{\text {th }} \text { pct. minus actual value } \\
\text { at } 10^{\text {th }} \text { pct. of earthquake experience }\end{array}$ & 0.002 & -0.026 & 75.733 \\
\hline $\begin{array}{l}\text { Average of fitted value at maximum minus fitted value } \\
\text { at minimum of earthquake experience }\end{array}$ & 0.046 & -0.379 & 395.977 \\
\hline \multicolumn{4}{|l|}{ Panel B: Magnitude $\geq 5$} \\
\hline Weighting parameter $\lambda$ & $\begin{array}{c}0.28 \\
{[\text { fixed }]}\end{array}$ & $\begin{array}{c}0.18 \\
{[\text { fixed] }}\end{array}$ & $\begin{array}{c}1.24 \\
\text { [fixed] }\end{array}$ \\
\hline Earthquake experience coefficient $\beta$ & $\begin{array}{c}0.063 \\
(0.009)\end{array}$ & $\begin{array}{l}-1.071 \\
(0.124)\end{array}$ & $\begin{array}{c}807.470 \\
(1512.808)\end{array}$ \\
\hline $\begin{array}{l}\text { Average of actual value at } 90^{\text {th }} \text { pct. minus actual value } \\
\text { at } 10^{\text {th }} \text { pct. of earthquake experience }\end{array}$ & 0.002 & -0.022 & 13.671 \\
\hline $\begin{array}{l}\text { Average of fitted value at maximum minus fitted value } \\
\text { at minimum of earthquake experience }\end{array}$ & 0.046 & -0.293 & 73.195 \\
\hline Bank-level controls & Yes & Yes & Yes \\
\hline Regional controls & No & Yes & Yes \\
\hline Headquarter fixed effects & Yes & Yes & No \\
\hline Year fixed effects & Yes & Yes & Yes \\
\hline Observations & 10625 & 10595 & 10545 \\
\hline Number of banks & 415 & 415 & 415 \\
\hline
\end{tabular}




\section{Table 9: Robustness: Borrower Credit Quality (Excluding Large Banks)}

This table reports estimates of regressions of the income of borrowers on earthquake experiences of banks and a series of bank- and regional-specific variables. The time horizon is 2010 to 2013. We first collect the income of individual borrowers from the HMDA dataset and then calculate the yearly average of the borrower income for each bank and use it as the dependent variable. To address the potential reverse-causality concern, we exclude all banks with assets above $\$ 2$ billion from my sample. We fix the shape parameter $\lambda$ at their previous values estimated in Table 4 . The standard errors robust to heteroscedasticity are reported in parentheses. The weighting parameters are shown in the first row. All the regressions control for year fixed effects.

\begin{tabular}{|c|c|c|c|}
\hline & (i) & (ii) & (iii) \\
\hline \multirow[t]{2}{*}{ Weighting parameter $\lambda$} & 1.16 & 1.16 & 1.24 \\
\hline & [fixed] & [fixed] & [fixed] \\
\hline \multirow[t]{2}{*}{ Earthquake experience coefficient $\beta$} & 631.162 & 630.942 & 522.954 \\
\hline & $(277.031)$ & $(293.373)$ & $(280.341)$ \\
\hline \multirow[t]{2}{*}{ NonHaz branch\% } & & -1.112 & 1.731 \\
\hline & & $(75.189)$ & $(77.838)$ \\
\hline \multirow[t]{2}{*}{ Branch number $\%$} & & & -6.209 \\
\hline & & & $(5.824)$ \\
\hline Bank-level controls & Yes & Yes & Yes \\
\hline Regional controls & Yes & Yes & Yes \\
\hline Year fixed effects & Yes & Yes & Yes \\
\hline Average of fitted value at $90^{\text {th }}$ pct. minus fitted value & 76.914 & 76.887 & 66.768 \\
\hline \multicolumn{4}{|l|}{ at $10^{\text {th }}$ pct. of earthquake experience } \\
\hline Average of fitted value at maximum minus fitted value & 386.371 & 386.237 & 344.355 \\
\hline \multicolumn{4}{|l|}{ at minimum of earthquake experience } \\
\hline$R$-squared & 0.196 & 0.184 & 0.171 \\
\hline Observations & 246 & 246 & 246 \\
\hline Number of banks & 92 & 92 & 92 \\
\hline
\end{tabular}




\section{Table 10: Robustness: Rescaling the Earthquake Magnitude}

The earthquake magnitudes in my data are based on the Richter Scale that is a base-10 logarithmic scale. However, for simplicity, the previous results treat the scale to be linear. In this table, we rescale the magnitudes by taking the natural exponential as well as the base-10 exponential respectively. The table reports regression estimates of earthquake experiences on capital ratio, real estate ratio, and borrowing income. We fix the shape parameter $\lambda$ at their previous values estimated using the full specifications.

\begin{tabular}{|c|c|c|c|}
\hline & Capital ratio & Real estate ratio & Borrower income \\
\hline & (i) & (ii) & (iii) \\
\hline \multicolumn{4}{|l|}{ Panel A: Natural Logarithm } \\
\hline \multirow[t]{2}{*}{ Weighting parameter $\lambda$} & 0.28 & 0.18 & 1.24 \\
\hline & [fixed] & [fixed] & [fixed] \\
\hline \multirow[t]{2}{*}{ Earthquake experience coefficient $\beta$} & $3.325 \times 10^{-4}$ & -0.010 & 30.590 \\
\hline & $(0.000)$ & $(0.001)$ & $(12.734)$ \\
\hline Average of actual value at $90^{\text {th }}$ pct. minus actual value & 0.002 & -0.031 & 75.910 \\
\hline at $10^{\text {th }}$ pct. of earthquake experience & & & \\
\hline Average of fitted value at maximum minus fitted value & 0.034 & -0.454 & 412.877 \\
\hline at minimum of earthquake experience & & & \\
\hline \multicolumn{4}{|l|}{ Panel B: Base-10 Logarithm } \\
\hline \multirow[t]{2}{*}{ Weighting parameter $\lambda$} & 0.28 & 0.18 & 1.24 \\
\hline & [fixed] & [fixed] & [fixed] \\
\hline \multirow[t]{2}{*}{ Earthquake experience coefficient $\beta$} & $1.801 \times 10^{-7}$ & $-8.049 \times 10^{-4}$ & 0.047 \\
\hline & $(0.000)$ & $(0.000)$ & $(0.025)$ \\
\hline Average of actual value at $90^{\text {th }}$ pct. minus actual value & 0.001 & -0.019 & 57.576 \\
\hline at $10^{\text {th }}$ pct. of earthquake experience & & & \\
\hline Average of fitted value at maximum minus fitted value & 0.036 & -0.192 & 323.607 \\
\hline Bank-level controls & Yes & Yes & Yes \\
\hline Regional controls & Yes & Yes & Yes \\
\hline Headquarter fixed effects & Yes & Yes & No \\
\hline Year fixed effects & Yes & Yes & Yes \\
\hline Observations & 16473 & 10545 & 280 \\
\hline Number of banks & 464 & 415 & 112 \\
\hline
\end{tabular}




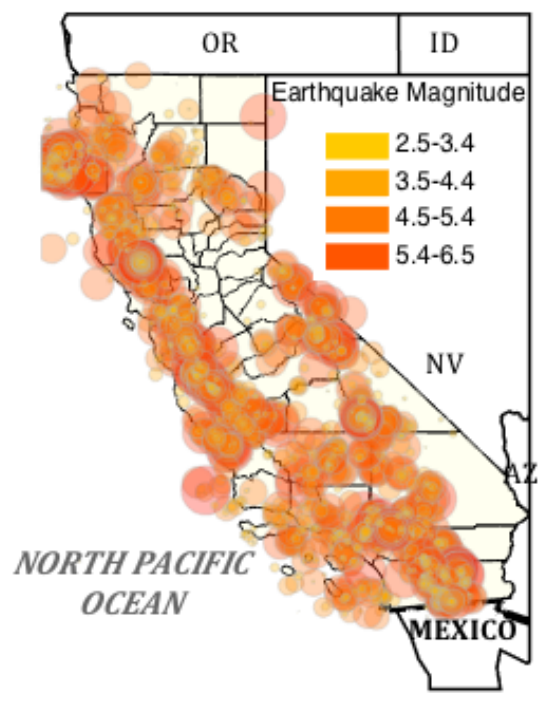

Figure 1: Earthquake Distribution of California (2006-2010). This map plots geographical locations of earthquakes of California for the period 2006-2010. Marker size and color darkness are both strictly increasing in earthquake magnitude $(\min =2.5, \max =6.5)$. The map shows 4818 earthquake events during this period. The data are obtained from the Search Earthquake Catalog of USGS.

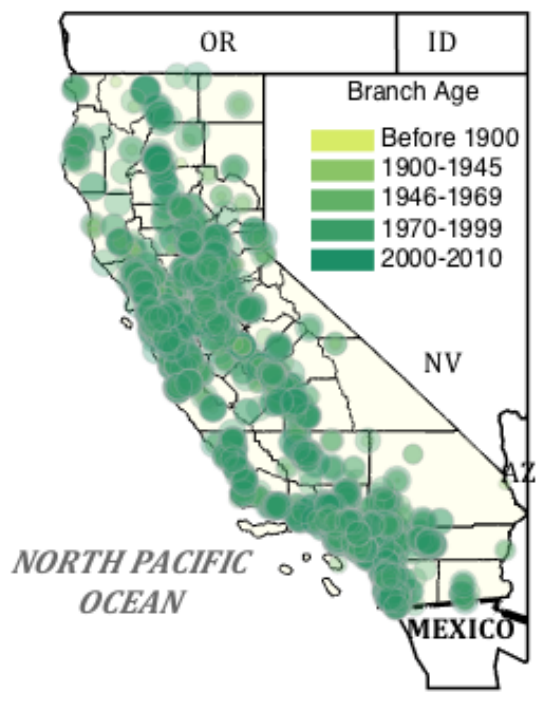

Figure 2: Bank Branch Distribution of California (2010). This map shows the distribution of branch offices of California banks by the date June 30, 2010. Marker size and color darkness are both strictly increasing in bank age (oldest: established on January 1, 1864; youngest: established on June 30,2010). The data source is the Branch Office Deposits data of FDIC. 


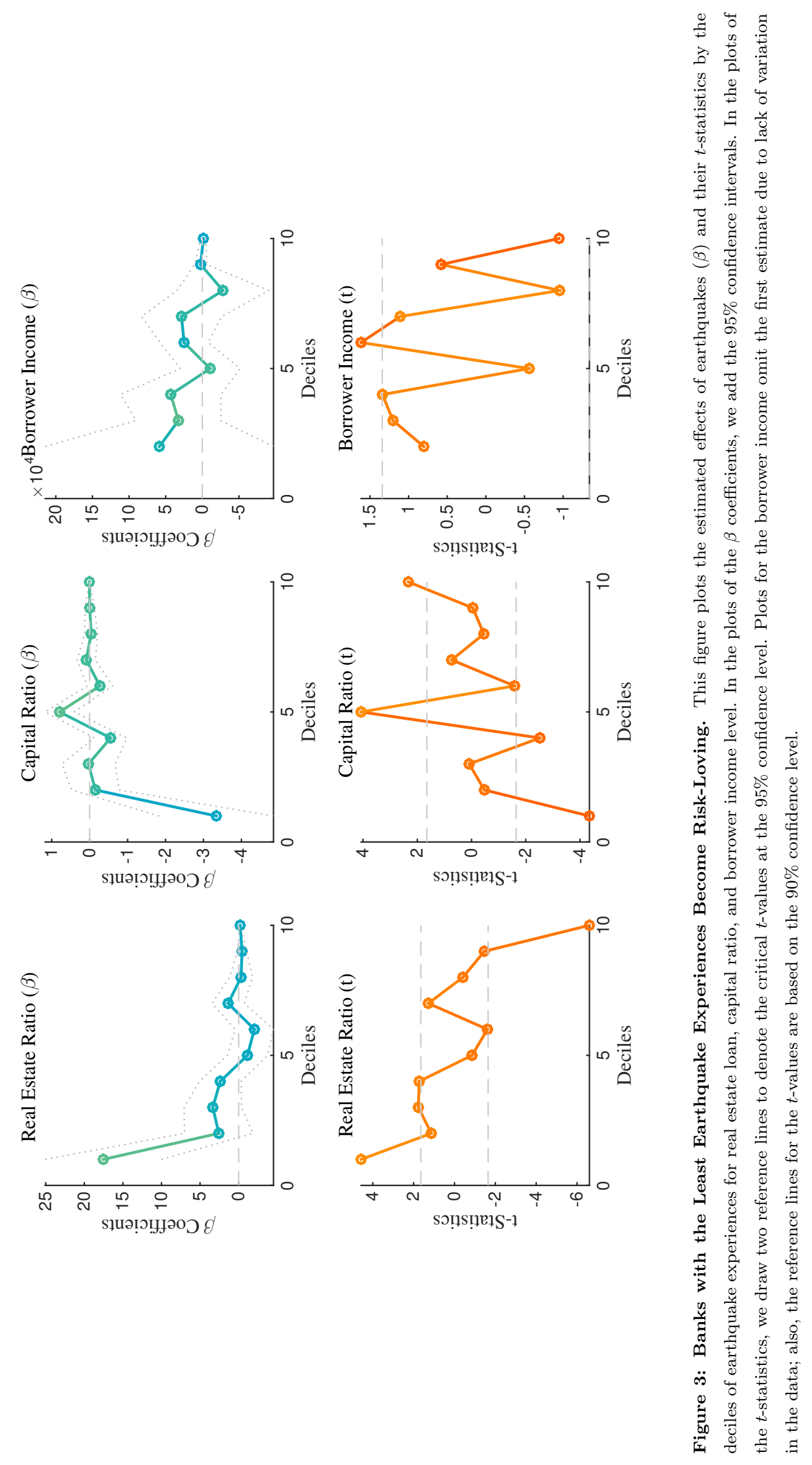




\section{Appendix}

\section{Table 11: Terminology}

This table lists definitions of the key concepts used in this paper and dependent and explanatory variables compiled from the original data.

\begin{tabular}{|c|c|}
\hline \multicolumn{2}{|l|}{ Concepts } \\
\hline California & $\begin{array}{l}\text { California is a state of U.S. located on the western (Pacific Ocean) coast. Its dominant } \\
\text { natural disasters are earthquake and wildfire. }\end{array}$ \\
\hline Natural disaster & $\begin{array}{l}\text { A natural disaster is a major adverse event resulting from natural processes of the } \\
\text { Earth; examples include floods, volcanic eruptions, earthquakes, tsunamis, and other } \\
\text { geologic processes. }\end{array}$ \\
\hline Earthquake & $\begin{array}{l}\text { An earthquake is the shaking of the surface of the Earth, resulting from the sudden } \\
\text { release of energy in the Earth's lithosphere that creates seismic waves. }\end{array}$ \\
\hline \multicolumn{2}{|l|}{ Dependent variables } \\
\hline Real estate ratio & Loans secured by real estate/total assets; source: Call Reports; frequency: quarterly. \\
\hline Capital ratio & $\begin{array}{l}\text { Total equity capital/(total assets+allowance for loan and lease losses+allocated trans- } \\
\text { fer risk reserves); also know as equity ratio, equity capital ratio, or capitalization; } \\
\text { source: Call Reports; frequency: quarterly. }\end{array}$ \\
\hline Borrower income & $\begin{array}{l}\text { Average borrower income (yearly) across all branches of a bank; source: HMDA } \\
\text { dataset; frequency: yearly. }\end{array}$ \\
\hline Borrower race & $\begin{array}{l}\text { Number of nonwhite borrowers/number of all borrowers of a bank; source: HMDA } \\
\text { dataset; frequency: yearly. }\end{array}$ \\
\hline \multicolumn{2}{|l|}{ Explanatory Variables } \\
\hline Bank/branch age & $\begin{array}{l}\text { The number of dates between the date of establishment and the date of the obser- } \\
\text { vation of the dependent variable. For instance, for the value of real estate ratio in } \\
\text { the } 4 \text { th quarter of } 2010 \text {, the bank/branch age equals } 2010-12-31 \text { minus the date of } \\
\text { establishment. }\end{array}$ \\
\hline Branch number & Number of branches of a bank; source: SOD dataset; frequency: yearly. \\
\hline Imputed interest rate & $\begin{array}{l}\text { Interest income/ outstanding loans of the last quarter; source: Call Reports; fre- } \\
\text { quency: quarterly. }\end{array}$ \\
\hline NonHaz region & $\begin{array}{l}\text { counties that has significantly less earthquakes, including replace Amador, Butte, } \\
\text { Calaveras, Colusa, El Dorado, Sacramento, San Joaquin, Stanislaus, Sutter, } \\
\text { Tuolumne, Yolo, and Yuba. }\end{array}$ \\
\hline NonHaz branch\% & The proportion of a bank's branches in the NonHaz region. \\
\hline $\mathrm{ROA}$ & $\begin{array}{l}\text { Return on assets. Net interest income/ total assets of the last quarter; source: Call } \\
\text { Reports; frequency: quarterly. }\end{array}$ \\
\hline
\end{tabular}




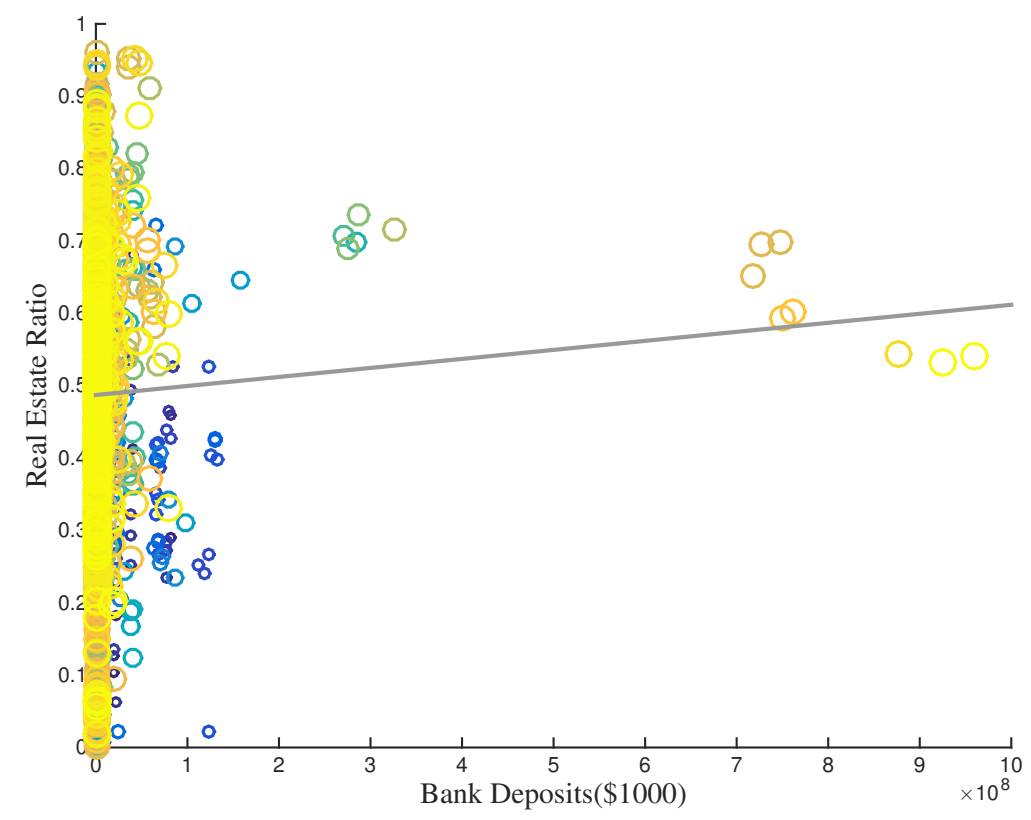

Figure 4: Closing the Circle: Positive Relationship between Bank Deposits and Real Estate Ratio. This scatter plot shows the relationship between bank-level deposits and real estate ratio. The sample is the same as used in Table 2.

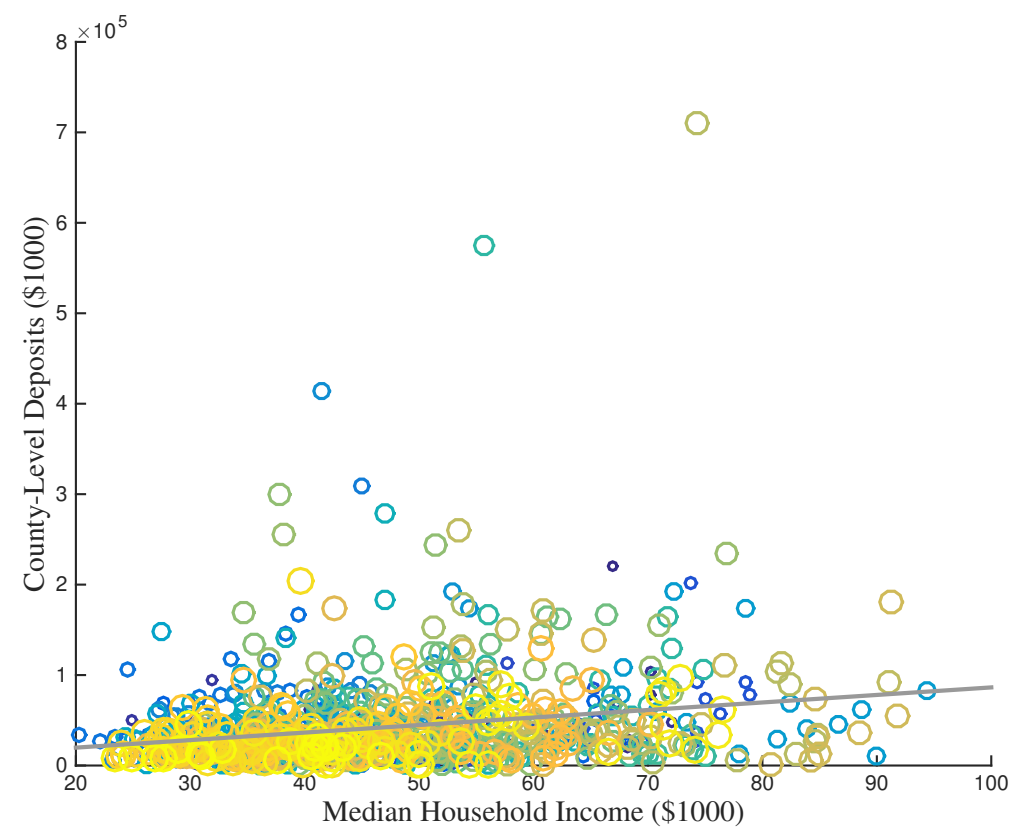

Figure 5: Closing the Circle: Positive Relationship between Median Household Income and County-Level Deposits. This scatter plot shows the relationship between county-level median household income and county-level bank deposits. The income data are from the U.S. Census Bureau and the deposit data are from the SOD dataset of FDIC. We sum branch-level deposit by county and year to get the county-level deposit. The fitted regression line confirms the positive relationship between the two variables. 